\title{
Environmental Kuznets Curve (EKC) in Australia: Evidence from Nonlinear ARDL Model with a Structural Break
}

\author{
Cihan Özden*, Emrah Beşe \\ Near East University, Mersin, Turkey
}

Received: 6 August 2020

Accepted: 15 September 2020

\begin{abstract}
In this study, whether economic growth leads to environmental degradation in Australia is analyzed since Australia has been growing consecutively for the last 28 years and is among the countries which are heavily dependent on fossil fuels for energy demands such as oil and coal. In this study, we aim to analyze the EKC hypothesis and the relationships between gross domestic product per capita (GDP in constant 2010 US\$), carbon dioxide emissions ( $\mathrm{CO}_{2}$ in metric tons per capita), energy consumption (ENE in $\mathrm{kg}$ of oil equivalent per capita) and square of GDP by the ARDL model (Autoregressive Distributed Lag Model) and nonlinear ARDL model (NARDL) to investigate whether the increase in economic growth leads to an increase in emissions. The relationships between economic growth and emissions is important since most of the countries in the world aim for economic growth and certain policy requirements should also be analyzed alongside this relationship to make economic growth and emissions relationship compatible. The main results of this study show that no asymmetric and no symmetric relationships are found between GDP and $\mathrm{CO}_{2}$. No causal relationship is found from GDP, square of GDP and ENE to $\mathrm{CO}_{2}$. The EKC hypothesis is not confirmed for Australia. Australia should continue its efforts for decreasing oil consumption, increasing renewable energy generation levels and supporting current market mechanisms which move in favor of renewable energy generation over fossil fuel consumption. Australia can continue its economic growth without concern that reducing $\mathrm{CO}_{2}$ emissions will negatively affect GDP.
\end{abstract}

Keywords: environmental Kuznets curve, ARDL model, Nonlinear ARDL model, Australia, Single-country studies

\section{Introduction}

In this study, we aim to analyze the EKC hypothesis and the relationships between $\mathrm{CO} 2$, GDP, square of GDP

*e-mail: 20159272@std.neu.edu.tr and ENE by the ARDL model and nonlinear ARDL model. According to the EKC hypothesis, $\mathrm{CO}_{2}$ levels initially increase as the country's GDP grows. After a certain level of GDP is achieved, $\mathrm{CO}_{2}$ levels start to decline. There is a scarcity for single country studies in the literature of EKC for Australia. Additionally, the study is important since Australia is heavily dependent 
on fossil fuels for energy demands and is among the top 11 countries in the world for energy demands on coal consumption. The investigation of the relationship between economic growth and emissions carry importance since climate change has been a hot topic for the last decade and maintaining certain economic growth while protecting the environment is particularly important.

Many of the studies for the analysis of EKC in Australia have used the ARDL model in the literature. According to Shahbaz and Sinha [1], the majority of studies apply the ARDL model in the general literature of single country studies for EKC. Since the ARDL model is the common methodology that is used in the literature and allows comparison with the other studies that have used the ARDL model as well, the ARDL model is chosen to be applied in this study. The spotted research gap of the literature is that nonlinear relationships between economic growth and emissions are not analyzed in detail and majority of the studies in the EKC literature focused on symmetric relationships between economic growth and emissions. The aim of this study is to fill the gap in the EKC literature by analyzing the asymmetric relationships between economic growth and emissions. Australia is also analyzed to fill the gap in the literature since relationship between economic growth and emissions is not analyzed in detail for Australia in the literature.

The main aims of this study are to contribute to the single country studies of EKC literature by using the NARDL model, introduce possible policy recommendations and introduce future research direction for the scope of single country studies.

The following hypotheses are tested for the relationships between $\mathrm{CO}_{2}$, GDP, square of GDP and ENE

$\mathrm{H} 1$ : There is symmetric cointegration between $\mathrm{CO}_{2}$, GDP, square of GDP and ENE in Australia.

$\mathrm{H} 2$ : There is asymmetric cointegration between $\mathrm{CO}_{2}$, GDP, square of GDP and ENE in Australia.

This section includes the literature review to examine the current studies in the literature for the EKC hypothesis. The following sections present Material and Methods, Results and Discussion, and Conclusions respectively. Material and Methods section explains the methodologies used in this study. Results and Discussion section discusses the results of this study and significance of the results. Conclusions section present the main results of the study with policy suggestions and future research suggestions.

For the research studies in the literature that examine the relationships between $\mathrm{CO}_{2}$, ENE and GDP for Australia as a single country study, Marques et al. [2] verified the EKC hypothesis for Australia for the period between 1965 and 2016 and found causality from GDP to $\mathrm{CO}_{2}$. Leal et al. [3] found bi-directional causality between $\mathrm{CO}_{2}$ and GDP in the long run for Australia for the period between 1965 and 2015. Shahbaz et al. [4] did not verify the EKC hypothesis for Australia for the period between 1970 and 2012 and found causality from ENE to $\mathrm{CO}_{2}$ for Australia in the short run. Salahuddin and Khan [5] found no cointegration between GPD, $\mathrm{CO}_{2}$ and ENE for Australia for the period between 1965 and 2007 and found bi-directional causality between ENE and GDP, and no causality between $\mathrm{CO}_{2}$ and GDP.

Marques et al., Leal et al. and Shahbaz et al. used the ARDL model, and Salahuddin and Khan used the Johansen cointegration model.

For the most up-to-date research studies for the NARDL model, Phiri [6] investigated relationships between economic growth, environmental degradation and business cycles in Eswatini for the period 1970 and 2014 by the NARDL model and found no EKC for Eswatini.

Boufateh [7] investigated relationships between real GDP, oil prices (CP) and emissions for the period between 1976 and 2013 for China and USA and found no EKC for China and USA.

Rahman and Ahmad [8] confirmed an asymmetric relationship between emissions and gross capital formation and EKC for Pakistan for the period between 1980 and 2016. Furthermore, Rahman and Ahmad found that coal consumption (CNS) and oil consumption (OCN) affected emissions significantly.

Iorember et al. [9] confirmed that renewable energy consumption (RW), trade openness (TT) and GDP had asymmetric effects on emissions for Nigeria and South Africa for the period between 1990 and 2014.

Munir and Ameer [10] confirmed that foreign direct investment (F), GDP and industrialization had asymmetric effects on emissions in Pakistan for the period between 1975 and 2016. Ahmad et al. [11] confirmed an asymmetric long-run relationship between emissions and remittances for China for the period between 1980 and 2014 .

Burakov and Bass [12] examined the relationship between emissions, corruption and income inequality for Russia for the period between 1996 and 2018 and confirmed that corruption led to increased emissions. Asymmetric cointegration between the variables are confirmed. Income inequality had an insignificant effect on emissions.

Rahman et al. [13] tested the pollution haven hypothesis for Pakistan for the period between 1975 and 2016 and confirmed a symmetric relationship between F inflow and emissions. Rahman et al. confirmed the EKC hypothesis and pollution haven hypothesis for Pakistan.

AhAtil et al. [14] investigated the impact of GDP, ENE, financial development (FND) and globalization (GB) on emissions for China for the period between 1970 and 2015 and confirmed that ENE had an asymmetric effect on emissions in the short run, and GDP, FND and GB had an asymmetric effect on emissions in the long run.

Haug and Ucal [15] investigated the effects of $\mathrm{F}$ and TT on emissions for the period between 1970 and 2014. Haug and Ucal also investigated the effects of F, TT, 
FND and urbanization on $\mathrm{CO}_{2}$ intensity and confirmed EKC for emissions and $\mathrm{CO}_{2}$ intensity. Additionally, asymmetric cointegration between F, TT and emissions was confirmed. Haug and Ucal found that $\mathrm{CO}_{2}$ intensity was positively affected by FND and urbanization but not by TT and F.

Toumi and Toumi [16] examined the asymmetric relationships between RW, emissions and economic growth in Saudi Arabia for the period between 1990 and 2014 and confirmed asymmetric cointegration between emissions and RW, GDP and emissions, and RW and GDP. Asymmetric causality from negative and positive components of emissions to GDP were found in the long run, and joint asymmetric causality from negative and positive components from RW and emissions to GDP were found in the long run. Toumi and Toumi found asymmetric causality from positive and negative components of emissions to RW.

Karasoy [17] found that non-RW, RW and TT had asymmetric effects on emissions in the long run, and RW had an asymmetric effect on emissions in the short run. Karasoy did not confirm EKC for Turkey.

Cosmas et al. [18] investigated the relationships between emissions, ENE, FND, GDP, population, CP and TT and confirmed an N-shaped relationship between emissions and GDP. Asymmetric and symmetric relationships between ENE, GDP, manufacturing and emissions were found. Cosmas et al. found a negative relationship between emissions and ENE.

Khan et al. [19] investigated the relationships between environmental regulation (ERG), FND, urban population growth, ENE, research and development and emissions and found no asymmetric cointegration between the variables. Khan et al. confirmed negative and significant linear relationships between ERG and emissions.

Luqman et al. [20] investigated the relationships between RW, economic growth, nuclear energy consumption, emissions, OCN and CP for Pakistan for the period between 1990 and 2016 and found that RW had a positive impact on GDP, that there was asymmetric cointegration between RW and GDP, that $\mathrm{CP}$ had an insignificant impact on RW, that there was asymmetric cointegration between emissions and RW and that there was asymmetric cointegration between GDP and nuclear energy.

Constantinos et al. [21] investigated the relationship between crude oil prices (CT) and emissions for the period between 1987 and 2015 and confirmed asymmetric cointegration between $\mathrm{CT}$ and emissions and bi-directional causality between $\mathrm{CT}$ and emissions.

Chen et al. [22] used the logarithmic mean Divisia index (LMDI) decomposition approach and the Tapio decoupling approach to examine the decoupling relationship between emissions and human development index in Southwest China, Chongqing, Sichuan, Guizhou and Yunnan, for the period 2000 and 2015. Chen et al. confirmed the EKC hypothesis only for Yunnan and the decoupling relationship between emissions and human development index for Southwest China.

Ma et al. [23] analyzed carbon emissions from residential buildings for China for the period 2000 and 2015 by projecting further emissions through 2050 for China's 2030 emission peak goal. Ma et al. found that carbon emissions from residential buildings will peak at 2037 and provided policy suggestions to meet China's 2030 emission peaks goals.

Literature review shows that the relationship between economic growth and emissions are analyzed with additional variables for asymmetric and symmetric relationships. Though asymmetric relationships are analyzed in the literature, further studies are required since most of the studies in the literature are for symmetric relationships between economic growth and emissions. Certain country of studies is also not analyzed in detail such as Australia. Asymmetric relationships between economic growth and emissions should be analyzed for the countries which are not studied in detail in the literature.

Current specific knowledge gap in the literature is that asymmetric relationships are not analyzed in detail. Also, current internal financial regulations of the countries can affect the way these countries finance their emissions for certain sectors such as construction and real estate. Asymmetric relationships between economic growth and emissions are considered alongside energy consumption in this study, and other variables may be considered in the future studies to further analyze the relationships between economic growth and emissions by also considering financing of certain sectors' emissions according to the country of studies' internal financial regulations. Emissions from residential buildings also carry importance to be examined for developing countries.

The analysis of the relationship between emissions and economic growth is important since most of the countries in the world give priority to the increase of economic growth, and the global warming also is one of the current top issues in the world. Analysis of certain policy requirements to maintain economic growth by lowering emissions and using natural resources more efficiently also carry importance.

\section{Material and Methods}

Unit root levels of variables are investigated with the unit root test (RT test) of Zivot and Andrews (H Test) [24]. Perron [25] stated that traditional RT tests may create biased results since traditional RT tests do not use structural breaks such as the $\mathrm{Ng}$ and Perron [26] RT test (P Test). Perron [25] stated that RT tests that do not use structural breaks may show unit root for a variable that does not exist in the presence of structural breaks. The $\mathrm{P}$ test is also used to show traditional RT test results for the variables. The $\mathrm{H}$ test model, which use the structural breaks 
in intercept and trend, and intercept, is used in this study as suggested by Sen [27].

Narayan's [28] critical bound values are used to compare with bounds test results since the sample size is small.

Akaike Information Criteria (AIC) is chosen to determine the lag length.

The Cusum (Stability Test A) and Cusum squares (Stability Test B) tests are used to determine the stability of the ARDL model results.

The Bayer and Hanck [29] combined cointegration tests (BH Tests) are applied first since the BH tests do not use the structural breaks in the data. The BH tests calculate Fisher-type statistics and test them against $5 \%$ critical values. The null hypothesis of the $\mathrm{BH}$ tests is that there is no cointegration between the tested variables.

The ARDL model with the unrestricted intercept and no trend of Pesaran et al. [30] is used in this study. The ARDL bounds test for cointegration is applied to examine the symmetric relationships between variables. The ARDL model is the common methodology that is used in the literature of EKC studies and is used in this study to compare the results with other studies in Australia. Breusch-Pagan-Godfrey Heteroskedasticity Test (BP Test), Breusch-Godfrey Serial Correlation LM Test (B test) and normality test ( $\mathrm{N}$ Test).
The nonlinear ARDL model by Shin et al. [31] with unrestricted intercept and no trend is applied to examine the asymmetric relationship between $\mathrm{CO}_{2}$, GDP, square of GDP and ENE since the ARDL model analyzes the symmetric relationship between variables and no symmetric relationship between variables is found. The stability of the nonlinear ARDL model is examined by the Stability Test A, Stability Test B, B Test, $\mathrm{N}$ test, BP Test and RESEt test (R Test).

The ARDL and NARDL models are applied including the structural break. Structural breaks are also included in further analysis with the ARDL and NARDL models. The EViews program is used for all calculations in this study.

The Gregory and Hansen [32, 33] tests (GH Test) are used in this study. The GH tests have three models to investigate the cointegration between the variables which are regime shift, level shift with trend and level shift models. All these three models are used in this study to investigate the relationships between the variables. The test results of each model are checked with the values given by Gregory and Hansen [33].

The EKC relationship between $\mathrm{CO}_{2}$ and GDP are examined by ENE, $\mathrm{CO}_{2}$, GDP and square of GDP nexus. The model that is applied in this study is as below. The estimated parameters in the model are h0, h1, h2 and $\mathrm{h} 3$. Time index is $\mathrm{t}$ and error term is e in both models.

Table 1. P Test.

\begin{tabular}{|c|c|c|c|c|c|}
\hline LNCO2 & & $\mathrm{MZa}$ & $\mathrm{MZt}$ & MSB & MPT \\
\hline Test statistics & & 0.14897 & 0.17913 & 1.20249 & 80.6862 \\
\hline \multicolumn{6}{|l|}{$\mathrm{D}(\mathrm{LNCO} 2)$} \\
\hline Test statistics & & $-26.2758^{*}$ & $-3.54897^{*}$ & $0.13507^{*}$ & $1.17771^{*}$ \\
\hline \multicolumn{6}{|l|}{ LNGDP } \\
\hline Test statistics & & 1.36841 & 1.46892 & 1.07345 & 85.0097 \\
\hline \multicolumn{6}{|l|}{$\mathrm{D}(\mathrm{LNGDP})$} \\
\hline Test statistics & & $-24.2412^{*}$ & $-3.48137 *$ & $0.14361 *$ & $1.01099 *$ \\
\hline \multicolumn{6}{|l|}{ LNGDP2 } \\
\hline Test statistics & & 1.41383 & 1.52403 & 1.07794 & 86.3901 \\
\hline \multicolumn{6}{|l|}{ D(LNGDP2) } \\
\hline Test statistics & & $-24.2029 *$ & $-3.47870^{*}$ & $0.14373 *$ & $1.01231 *$ \\
\hline \multicolumn{6}{|l|}{ LNENE } \\
\hline Test statistics & & 0.46073 & 0.61042 & 1.32490 & 104.002 \\
\hline \multicolumn{6}{|l|}{ D(LNENE) } \\
\hline Test statistics & & $-26.3732 *$ & $-3.56088^{*}$ & $0.13502 *$ & $1.15728^{*}$ \\
\hline \multirow{3}{*}{$\mathrm{ACV}$} & $1 \%$ & -13.8000 & -2.58000 & 0.17400 & 1.78000 \\
\hline & $5 \%$ & -8.10000 & -1.98000 & 0.23300 & 3.17000 \\
\hline & $10 \%$ & -5.70000 & -1.62000 & 0.27500 & 4.45000 \\
\hline
\end{tabular}

Notes: * denotes the statistical significance for $1 \%$ levels. ACV denotes asymptotic critical values.

Source: Authors' Calculations. 
Table 2. H Test.

\begin{tabular}{|c|c|c|c|c|c|c|c|c|}
\hline & Intercept & Lag & Break & Result & Trend + Intercept & Lag & Break & Result \\
\hline LNCO2 & -1.767175 & 0 & 1977 & & -2.146336 & 0 & 1978 & \\
\hline DLNCO2 & $-8.398569^{*}$ & 0 & 1993 & $\mathrm{I}(1)$ & $-8.769331^{*}$ & 0 & 2005 & $\mathrm{I}(1)$ \\
\hline LNGDP & -2.113969 & 0 & 1978 & & -3.119936 & 0 & 1973 & \\
\hline DLNGDP & $-6.912995^{*}$ & 0 & 1993 & $\mathrm{I}(1)$ & $-7.183015^{*}$ & 0 & 1971 & $\mathrm{I}(1)$ \\
\hline LNGDP2 & -2.294873 & 0 & 1997 & & -3.052157 & 0 & 1973 & 1971 \\
\hline DLNGDP2 & $-6.903919^{*}$ & 0 & 1993 & $\mathrm{I}(1)$ & $-7.097735^{*}$ & 0 & $\mathrm{I}(1)$ \\
\hline LNEN & -2.446864 & 9 & 2005 & & -3.300569 & 9 & 2007 & \\
\hline DLNEN & $-5.821035^{*}$ & 5 & 1993 & $\mathrm{I}(1)$ & $-5.589163^{*}$ & 5 & 1993 & $\mathrm{I}(1)$ \\
\hline
\end{tabular}

Notes: * denotes the statistical significance for $1 \%$ levels.

Source: Authors' Calculations.

$$
\begin{gathered}
\ln (C O 2)_{t}=h_{0}+h_{1} \ln (G D P)_{t}+h_{2} \ln (G D P)_{t}{ }^{2}+ \\
h_{3} \ln (E N E)_{t}+e_{t}
\end{gathered}
$$

The ARDL model is specified as below for the emissions, growth and energy consumption nexus.

$$
\begin{aligned}
& \Delta \operatorname{LnCO}_{t}=J_{0}+J_{1} \operatorname{LnCO}_{t-1}+J_{2} \operatorname{LnGDP} P_{t-1}+ \\
& J_{3} \operatorname{LnGDP}_{t-1}^{2}+J_{4} \operatorname{LnENE}_{t-1}+\sum_{i=1}^{S} J_{5 i} \operatorname{LnCO}_{t-i}+ \\
& \sum_{i=0}^{h} J_{6 i} \operatorname{LnGDP}_{t-i}+\sum_{i=0}^{h} J_{7 i} \operatorname{LnGDP}^{2}{ }_{t-i}+
\end{aligned}
$$

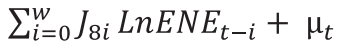

$\mu_{t}$ is for white noise residuals. $J_{1}, J_{2}, J_{3}$ and $J_{4}$ are long run coefficients. $J_{5} J_{6}, J_{7}$ and $J_{8}$ are short run coefficients.

Hypothesis of no cointegration is $J_{1}, J_{2}, J_{3}$ and $J_{4}$ are all equal each other and zero.

Hypothesis of cointegration is $J_{1}, J_{2}, J_{3}$ and $J_{4}$ are not all equal each other and zero.

The NARDL model is specified as below for the emissions, growth and energy consumption nexus.

$$
\begin{gathered}
\Delta \operatorname{LnCO}_{t}=Z_{0}+Z_{1} \operatorname{LnCO}_{t-1}+Z_{2} \operatorname{LnGDP}_{t-1}+ \\
Z_{3} \operatorname{LnGDP}_{t-1}^{+}+Z_{4} \operatorname{LnGDP}_{t-1}{ }_{t-1}+Z_{5} \operatorname{LnENE}_{t-1}+ \\
\sum_{i=1}^{S} Z_{6 i} \operatorname{LnCO}_{t-i}+\sum_{i=0}^{h} Z_{7 i} \operatorname{LnGDP}_{t-i}+\sum_{i=0}^{h} Z_{8 i} \operatorname{LnGDP}_{t-i}+ \\
\sum_{i=0}^{w} Z_{9 i} \operatorname{LnGDP}_{t-i}+\sum_{i=0}^{w} Z_{10 i} \operatorname{LnENE}_{t-i}+\mu_{t}
\end{gathered}
$$

$\mu_{t}$ is for white noise residuals. $Z_{1}, Z_{2}, Z_{3}, Z_{4}$, and $Z_{5}$ are long-run coefficients. $Z_{6}, Z_{7}, Z_{8}, Z_{9}$, and $Z_{10}$ are short-run coefficients.

Hypothesis of no cointegration is $Z_{1}, Z_{2}, Z_{3}, Z_{4}$, and $Z_{5}$ are zero and all equal each other.

Hypothesis of cointegration is $Z_{1}, Z_{2}, Z_{3}, Z_{4}$, and $Z_{5}$ are not zero and not all equal each other.

The Toda-Yamamoto [34] Granger non-causality test (TY test) is applied. First the VAR model is established, and then the stability tests are applied. After the VAR model that satisfies the stability tests is established, the
TY test is applied for $\mathrm{CO}_{2}$, GDP, square of GDP and ENE.

The data is obtained from the official web site World Bank. The time period analyzed is between 1960 and 2014.

\section{Results and Discussion}

The BH tests are applied first. According to the Fisher-type statistics for the Engle-Granger, Johansen, Banerjee and Boswijk tests, no cointegration is found between the variables (see Table 9).

Symmetric and asymmetric relationships between $\mathrm{CO}_{2}$, GDP, square of GDP and ENE are found by the ARDL and NARDL models by including the structural break. The GH test is also applied for the relationship between $\mathrm{CO}_{2}$, GDP, square of GDP and ENE. Maximum lag lengths are chosen (see Table 3). The ARDL and NARDL models determine the optimum lag lengths (see Fig. 1 and 4). Variables are at I(1) levels (see Table 1 and Table 2). The ARDL and the NARDL models are stable according to the stability test results (see Table 5 and 6, Fig. 2, 3, 5 and 6). 1993 is used as a break date in the ARDL and NARDL models since 1993 is the only break date that satisfies the stability

Table 3. Lag Length Results.

\begin{tabular}{|c|c|c|}
\hline Lag & AIC & SC \\
\hline 0 & -11.72969 & -11.42666 \\
\hline 1 & $-21.97072 *$ & $-21.06163^{*}$ \\
\hline 2 & -21.68691 & -20.17175 \\
\hline 3 & -21.41718 & -19.29596 \\
\hline 4 & -21.31601 & -18.58873 \\
\hline
\end{tabular}

Note: SC resembles Schwarz Information Criteria. Source: Authors' Calculations. 
Table 4. Bounds Test Results.

\begin{tabular}{|c|c|c|c|c|c|}
\hline & & \multicolumn{2}{|c|}{$5 \%$} & & \\
\hline Break & F-Statistics & I0 Bound & I1 Bound & Model & $\begin{array}{c}\text { Durbin Watson } \\
\text { Statistics }\end{array}$ \\
\hline 1993 & 3.097638 & 3.23 & 4.35 & ARDL & 2.232868 \\
\hline 1993 & 2.199841 & 2.86 & 4.01 & NARDL & 2.143093 \\
\hline
\end{tabular}

Source: Authors' Calculations.

tests. In the NARDL model, GDP is decomposed into positive and negative components while square of GDP and energy consumption are used as control variables. According to the F-statistics values of the ARDL and NARDL bounds tests, no cointegration exists (see Table 4).

The GH cointegration test is applied after the ARDL and NARDL models, which uses one structural break in the model. The GH models include 1978 as the structural breaks in the model (see Table 7). T statistics, $\mathrm{Za}$ statistics and $\mathrm{Zt}$ statistics for three models of the $\mathrm{GH}$ test are not significant at $1 \%$ and $5 \%$ critical values (see Table 7 and Table 8).

Since no cointegration is found, the TY test is applied. The VAR model is established and it satisfies the stability test results (see Table 11, 12 and 13).

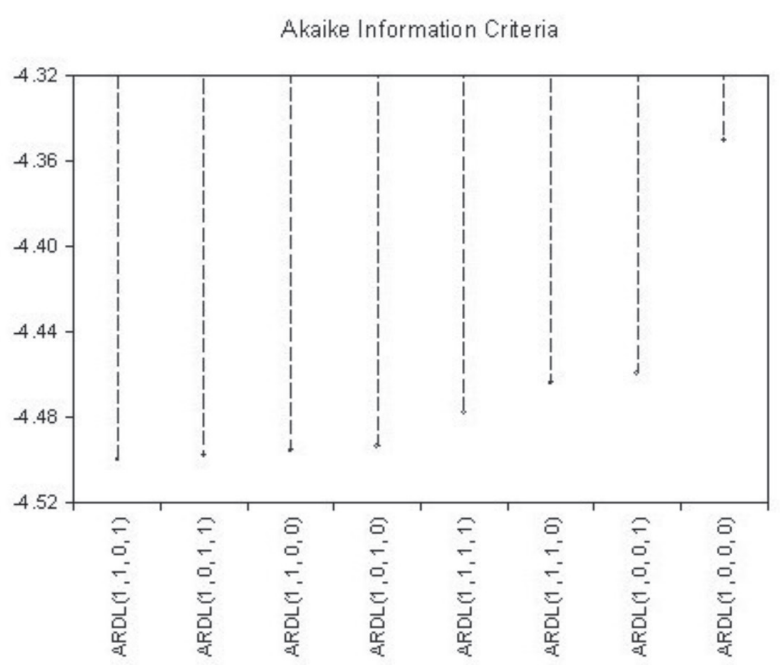

Fig. 1. ARDL Model Graph.
According to the TY test results, no causality exists from GDP, square of GDP and ENE to CO2 in the short run (see Table 10).

Environmental Kuznets Curve for Australia is not confirmed by the BH tests, ARDL and NARDL bounds tests and the $\mathrm{GH}$ tests.

The importance of the results is that Australia can continue further for economic development without concern that increasing and maintaining economic growth that would cause emissions. Economic growth can go along with emission reduction targets in the case of Australia. Different econometric techniques are applied in this study to examine the relationships between energy consumption, emissions and economic growth. The symmetric relationships are analyzed with the $\mathrm{BH}$ tests, ARDL bounds tests and the GH tests. The asymmetric relationships are analyzed with NARDL bounds tests. Structural breaks are also considered. By using different techniques in the case of Australia,

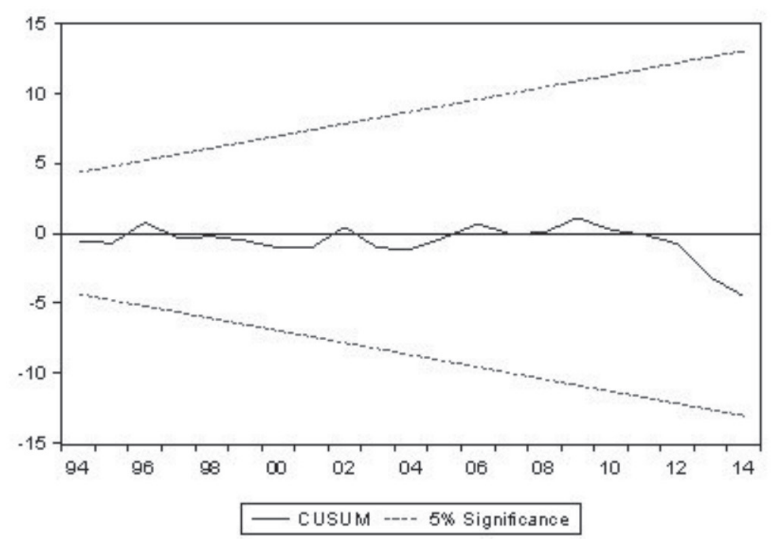

Fig. 2. Stability Test A for ARDL Model.

Table 5. ARDL Model Stability Test.

\begin{tabular}{|c|c|c|c|}
\hline Stability Test & F-Statistics & Probability & Jarque-Bera Statistics \\
\hline R Test & 0.849487 & 0.3616 & - \\
\hline Heteroskedasticity Test & 1.326894 & 0.2595 & - \\
\hline Correlation Test & 1.553104 & 0.2191 & 3.945601 \\
\hline Normality Test & - & 0.139067 & \\
\hline Source: Authors' Calculations. & & & \\
\hline
\end{tabular}




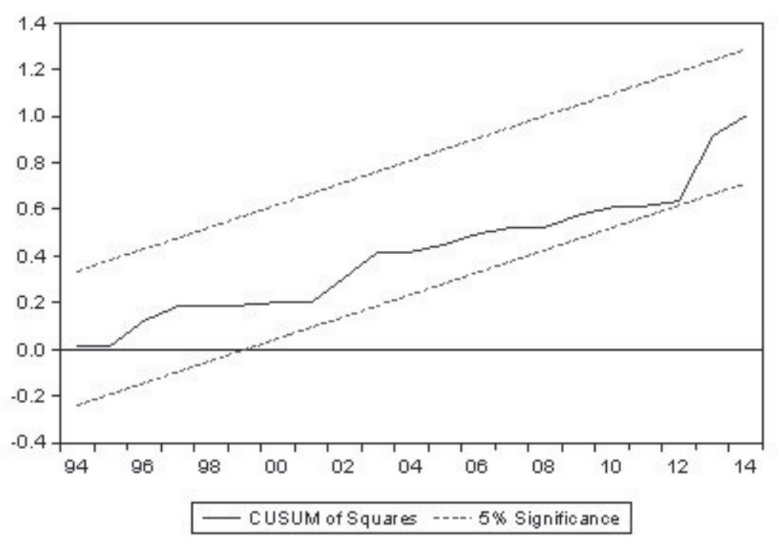

Fig. 3. Stability Test B for ARDL Model.

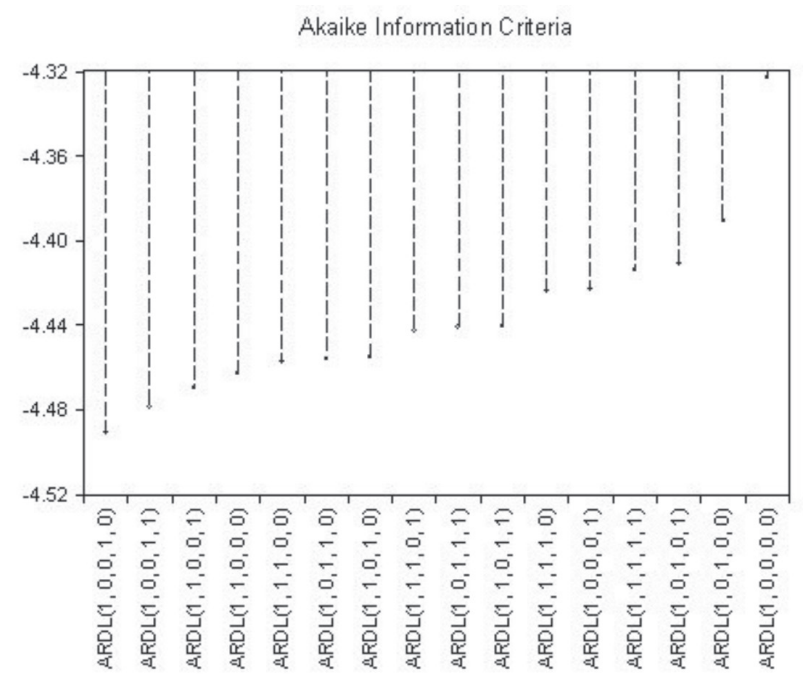

Fig. 4. NARDL Model Graph.

this study tests the EKC hypothesis for Australia and compares the results with the other studies in the literature. The EKC hypothesis has advantages and shortcomings. Overall, the EKC hypothesis has been beneficial in the literature to study the relationships between different indicators of environmental degradation and economic growth. For shortcomings of the EKC hypothesis, different econometric techniques can provide different results. In the case of Australia, this study contributes to the literature by including

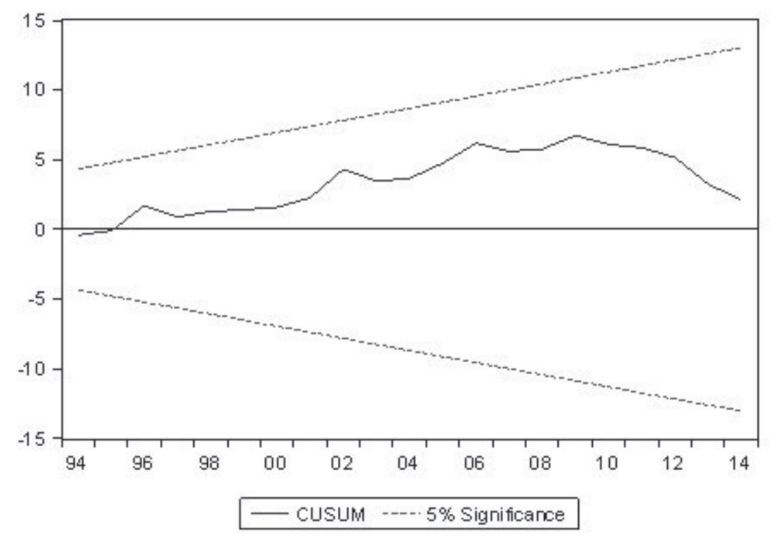

Fig. 5. Stability Test A for NARDL Model.

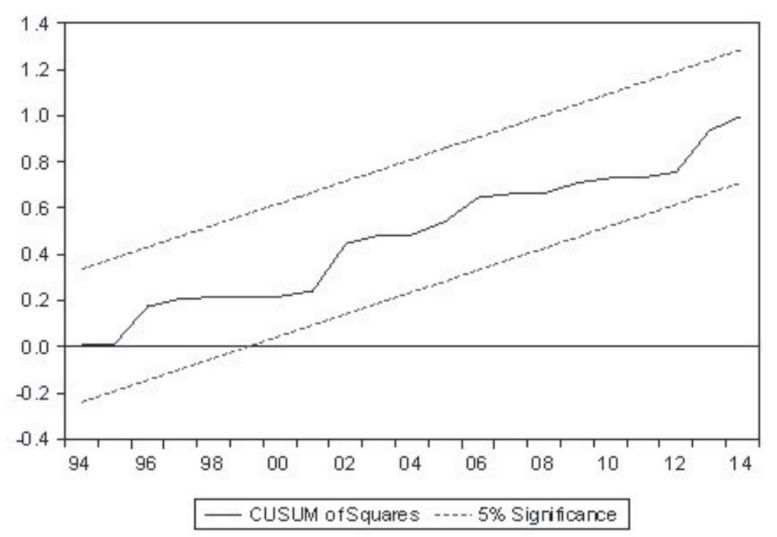

Fig. 6. Stability Test B for NARDL Model.

structural breaks and analyzing the asymmetric relationship between emissions and economic growth. The ARDL model only examines the symmetric relationships between the variables and in that case there might be a hidden relationship between the variables that may not be found with the ARDL model, so the asymmetric cointegration models are used such as the NARDL model.

Another shortcoming of the EKC hypothesis is that it only considers one turning point. In this study the EKC hypothesis is not found but as in the case of the EKC hypothesis is found, there might occur $\mathrm{N}$-shaped curve where multiple turning points may happen after

Table 6. NARDL Model Stability Test.

\begin{tabular}{|c|c|c|c|}
\hline Stability Test & F-Statistics & Probability & Jarque-Bera Statistics \\
\hline R Test & 0.039382 & 0.8436 & - \\
\hline Heteroskedasticity Test & 1.230878 & 0.3057 & - \\
\hline Correlation Test & 0.524775 & 0.4726 & 2.652674 \\
\hline Normality Test & - & 0.265448 & - \\
\hline
\end{tabular}

Source: Authors' Calculations. 
Table 7. GH Test.

\begin{tabular}{|c|c|c|c|}
\hline Model & Level Shift & Regime Shift & Level Shift with Trend \\
\hline \multicolumn{4}{|c|}{ ADF Procedure } \\
\hline T statistics & -4.214769 & -5.222430 & -5.373122 \\
\hline Break & 1978 & 1978 & 1978 \\
\hline \multicolumn{4}{|c|}{ Philips Procedure } \\
\hline Za Statistics & -28.63301 & -40.09428 & -39.43582 \\
\hline Break & 1978 & 1978 & 1978 \\
\hline Zt Statistics & -4.230459 & -5.271468 & -5.423575 \\
\hline Break & 1978 & 1978 & 1978 \\
\hline
\end{tabular}

Source: Authors' Calculations.

one turning point. For example, efficiency in resource usage may not go along with the same level alongside economic growth, so emissions may again start to increase again in the future levels of economic growth. Different policy recommendations should also be given for a case like $\mathrm{N}$-shaped curve relationship between emissions and economic growth.

Using different variables alongside energy consumption, economic growth and emissions may affect the real outcome of the relationships between the variables. Also, economic growth and emissions can be analyzed by not considering energy consumption. Using different models may bring different results for the same country of study. Analyzing a country with single country models and panel country models also may bring different results for the same country of study.

Table 8. Critical Values for GH Test.

\begin{tabular}{|c|c|c|}
\hline $\mathrm{ADF}, \mathrm{Zt}$ & .01 & .05 \\
\hline $\mathrm{C}$ & -5.77 & -5.28 \\
\hline $\mathrm{C} / \mathrm{T}$ & -6.05 & -5.57 \\
\hline $\mathrm{C} / \mathrm{S}$ & -6.51 & -6.00 \\
\hline $\mathrm{Z} \alpha$ & & \\
\hline $\mathrm{C}$ & -63.64 & -53.58 \\
\hline $\mathrm{C} / \mathrm{T}$ & -70.27 & -59.76 \\
\hline $\mathrm{C} / \mathrm{S}$ & -80.15 & -68.94 \\
\hline
\end{tabular}

The relationship between emissions and growth may become complex depending on the country of study's size, industry structure, level of technology and demand for environmental quality.

Table 10. TY Test.

\begin{tabular}{|c|c|c|c|}
\hline Excluded & Chi-sq & df & Prob. \\
\hline GDP & 3.865488 & 3 & 0.2764 \\
\hline GDP2 & 3.917530 & 3 & 0.2705 \\
\hline ENE & 2.725968 & 3 & 0.4358 \\
\hline All & 9.302788 & 9 & 0.4098 \\
\hline
\end{tabular}

Source: Authors' Calculations.

Table 11. N Test.

\begin{tabular}{|c|c|c|c|}
\hline Component & Jarque-Bera & Df & Prob. \\
\hline 1 & 1.795771 & 2 & 0.4074 \\
\hline 2 & 1.865356 & 2 & 0.3935 \\
\hline 3 & 2.501137 & 2 & 0.2863 \\
\hline 4 & 1.978563 & 2 & 0.3718 \\
\hline Joint & 8.140827 & 8 & 0.4198 \\
\hline
\end{tabular}

Source: Authors' Calculations.

Table 9. BH Test.

\begin{tabular}{|c|c|c|c|}
\hline Null Hypothesis: No Cointegration & Fisher Type Test Statistics & 5\% Critical Value & Result \\
\hline EG-J & 9.1425774 & 10.637 & No Cointegration \\
\hline EG-J-Ba-Bo & 15.112779 & 20.486 & No Cointegration \\
\hline
\end{tabular}

Note: EG-J resembles Engle and Granger, and Johansen. Ba-Bo resembles Banerjee and Boswijk.

Source: Authors' Calculations. 
Table 12. Test for Serial Correlation.

\begin{tabular}{|c|c|c|}
\hline Lags & LM-Stat & Prob \\
\hline 1 & 13.32751 & 0.6487 \\
\hline 2 & 13.01692 & 0.6715 \\
\hline 3 & 13.76903 & 0.6159 \\
\hline
\end{tabular}

Source: Authors' Calculations.

Table 13. Heteroskedasticity Test.

\begin{tabular}{|c|c|c|}
\hline Chi-sq & df & Prob. \\
\hline 195.5481 & 220 & 0.8810 \\
\hline
\end{tabular}

Source: Authors' Calculations.

\section{Conclusions}

Main findings of this study are as below.

1. Symmetric relationships between ENE, $\mathrm{CO}_{2}$, GDP and square of GDP are not confirmed in this study.

2. Asymmetric relationships between ENE, $\mathrm{CO}_{2}$, GDP and square of GDP are not confirmed in this study.

Since cointegration between ENE, $\mathrm{CO}_{2}$, GDP and square of GDP is also not confirmed by the GH tests and $\mathrm{BH}$ tests, the EKC hypothesis is not confirmed for Australia. No causality from GDP, square of GDP and ENE to $\mathrm{CO}_{2}$ is found in this study. Hypothesis 1 and hypothesis 2 are not confirmed in this study. The previous studies in the literature for Australia did not include a structural break and did not test the EKC hypothesis by asymmetric cointegration. Our results for the EKC hypothesis are in line with Shahbaz et al. and Salahuddin and Khan, both of which did not confirm the EKC hypothesis for Australia. Our results are different from the results of Marques et al. and Leal et al. which confirmed the EKC hypothesis for Australia.

Australia should continue is efforts for decreasing oil consumption, increasing renewable energy generation levels and supporting current market mechanisms which moves in favor of renewable energy generation over fossil fuel consumption. Australia can continue its economic growth without concern that reducing $\mathrm{CO}_{2}$ emissions will negatively affect GDP.

For further policy recommendations, Australia should increase its investment on public transportation since public transportation is not at adequate level for Australian cities. Increase in usage of public transportation may decrease passenger vehicle usage which is beneficial for emission reduction. Funding for climate change adaptation should be maintained for long term. Australia is still dependent on coal for energy demand. Taxation on coal consumption should be increased to increase the closure of coal plants for energy production and support renewable energy production. Emissions from transport sector has the second highest amount of emissions after energy sector.
Australian car fleet is inefficient for fuel consumption. Australia should provide incentives to replace its inefficient car fleet with fuel efficient cars. Taxes for fuel consumption in transport sector is low compared to international prices. Australia should increase taxation on fuel consumption to increase the fuel efficiency in transport sector. Taxation for fuel usage for energy production should also be increased. There are thousands of abandoned mines around Australia. Abandoned mines should be monitored regularly and necessary actions should be taken. Efforts and funding should be increased to protect biodiversity. Monitoring for protecting biodiversity should be improved. Efforts for recycling materials should be increased. Waste management should be improved to protect environment and gain economic benefits from recycling material industry. Monitoring for the impact of agriculture on environment is not sufficient in Australia. Monitoring for the impact of agriculture on environment should be improved especially for water quality and soil erosion.

The time period analyzed, which is from 1960 and 2014, and the country of the study which is Australia are the limits of this study.

For future research directions, nonlinear cointegration models may be used for further studies in Australia since the majority of studies have used symmetric cointegration models. The EKC relationship may be analyzed only between $\mathrm{CO}_{2}$ and GDP by taking ENE out of the equation for Australia as EKC has been analyzed by Jaforullah and King [35] for Denmark, Iceland, Canada, Finland, Norway, USA and Sweden.

\section{Acknowledgements}

The authors of this study are thankful to this journal's Executive Editor Prof. Hanna Radecka and Editor-in-Chief Prof. Jerzy Radecki for showing the necessary structural changes and the initial revie. We would like to thank to reviewers for their valuable comments that enabled us to improve the manuscript.

\section{Conflict of Interest}

The authors declare no conflict of interest.

\section{References}

1. SHAHBAZ M., SINHA A. Environmental Kuznets Curve for $\mathrm{CO}_{2}$ Emission: A Literature Survey. MPRA Paper, 86281, 2018.

2. MAR QUES A.C., FUINHAS J.A., LEAL P.A. The impact of economic growth on $\mathrm{CO}_{2}$ emissions in Australia: the environmental Kuznets curve and the decoupling index. Environmental Science and Pollution Research, 25, 27283, 2018.

3. LEAL P.H., ANTONIO CARDOSO MAR QUES, FUINHAS J.A. How economic growth in Australia 
reacts to $\mathrm{CO}_{2}$ emissions, fossil fuels and renewable energy consumption. International Journal of Energy Sector Management, 12 (4), 696, 2018.

4. SHAHBAZ M., BHATTACHARYA M., AHMED K. $\mathrm{CO}_{2}$ emissions in Australia: economic and non-economic drivers in the long-run. Applied Economics, 49 (13), 1273, 2017.

5. SALAHUDDIN M., KHAN S. Empirical Link Between Economic Growth, Energy Consumption and $\mathrm{CO}_{2}$ Emission in Australia. The Journal of Developing Areas, 47 (2), 81, 2013.

6. PHIRI A. Economic growth, Environmental degradation and business cycles in Eswatini. Munich Personal Repec Archive, 94993, 2019.

7. BOUFATEH T. The environmental Kuznets curve by considering asymmetric oil price shocks: evidence from the top two. Environmental Science and Pollution Research, 26, 706, 2019

8. RAHMAN Z.U., AHMAD M. Modeling the relationship between gross capital formation and $\mathrm{CO}_{2}$ (a)symmetrically in the case of Pakistan: an empirical analysis through NARDL approach. Environmental Science and Pollution RESEARCH, 26, 8111, 2019.

9. IOREMBER P.T., USMAN O., JELILOV G. Asymmetric Effects of Renewable Energy Consumption, Trade Openness and Economic Growth on Environmental Quality in Nigeria and South Africa. Munich Personal Repec Archive, 96333, 2019.

10. MUNIR K., AMEER A. Nonlinear effect of FDI, economic growth, and industrialization on environmental quality. Management of Environmental Quality: An International Journal. 2019.

11. AHMAD M., HAQ Z.U., KHAN Z., KHATTAK S.I., UR RAHMAN Z., KHAN S. Does the inflow of remittances cause environmental degradation? Empirical evidence from China. Economic Research-Ekonomska Istraživanja, 32 (1), 2099, 2019.

12. BURAKOV D., BASS A. Institutional determinants of environmental pollution in russia: a non- linear ardl approach. Entrepreneurship and Sustainability Issues, 7 (1), 510, 2019.

13. RAHMAN Z.U., CHONGBO W., AHMAD M. An (a) symmetric analysis of the pollution haven hypothesis in the context of Pakistan: a non-linear approach. Carbon Management, 10 (3), 227, 2019.

14. AHATIL A., BOUHENI F. BEN, LAHIANI A., SHAHBAZ M. Factors influencing $\mathrm{CO}_{2}$ Emission in China: A Nonlinear Autoregressive Distributed Lags Investigation. Munich Personal Repec Archive, 91190, 2019.

15. HAUG A.A., UCAL M. The role of trade and FDI for $\mathrm{CO}_{2}$ emissions in Turkey: Nonlinear relationships. Energy Economics, 81, 297, 2019.

16. TOUMI S., TOUMI H. Asymmetric causality among renewable energy consumption, $\mathrm{CO}_{2}$ emissions, and economic growth in KSA: evidence from a non-linear ARDL model. Environmental Science and Pollution Research, 26, 16145, 2019.

17. KARASOY A. Drivers of carbon emissions in Turkey: onsidering asymmetric impacts. Environmental Science and Pollution Research, 26, 9219, 2019.

18. COSMAS N.C., CHITEDZE I., MOURAD K.A. An econometric analysis of the macroeconomic determinants of carbon dioxide emissions in Nigeria. Science of the Total Environment, 675, 313, 2019.

19. KHAN Z., SISI Z., SIQUN Y. Environmental regulations an option: Asymmetry effect of environmental regulations on carbon emissions using non-linear ARDL Environmental regulations an option: Asymmetry effect of. Energy Sources, Part A: Recovery, Utilization, and Environmental Effects, 41 (2), 137, 2019.

20. LUQMAN M., AHMAD N., BAKHSH K. Nuclear energy, renewable energy and economic growth in Pakistan: vidence from non-linear autoregressive distributed lag model. Renewable Energy, 139, 1299, 2019.

21. CONSTANTINOS K., ELENI Z., NIKOLAOS S., ANTIS D. Greenhouse gas emissions - crude oil prices: an empirical investigation in a nonlinear framework. Environment, Development and Sustainability, 21, 2835, 2019.

22. CHEN L., CAI W., MA M. Decoupling or delusion? Mapping carbon emission per capita based on the human development index in Southwest China. Science of the Total Environment, 741, 2020.

23. MA M., MA X., CAI W., CAI W. Low carbon roadmap of residential building sector in China: Historical mitigation and prospective peak. Applied Energy, 273, 2020.

24. ZIVOT E., ANDREWS D.W.K. Further Evidence on the Great Crash, the Oil-Price Shock, and the Unit-Root Hypothesis. Journal of Business \& Economic Statistics, 10 (3), 25, 1992

25. PERRON P. Testing for a Unit Root in a Time Series With a Changing Mean. Econometrica, 8 (2), 153, 1990.

26. NG S., PERRON P. Lag Length Selection and the Construction of Unit Root Tests with Good Size and Power. Econometrica, 69 (6), 1519, 2001.

27. SEN A. On unit-root tests when the alternative is a trend-break stationary process. Journal of Business and Economic Statistics, 21 (1), 174, 2003.

28. NARAYAN P.K. The saving and investment nexus for China: evidence from cointegration tests. Applied Economics, 37 (17), 1979, 2005.

29. BAYER C., HANCK C. Combining non-cointegration tests. Journal of Time Series Analysis, 34 (1), 83, 2013.

30. PESARAN M.H., SHIN Y., SMITH R.J. Bounds testing approaches to the analysis of level relationships. Journal of Applied Econometrics, 16 (3), 289, 2001.

31. SHIN Y., YU B., GREENWOOD-NIMMO M. Modelling Asymmetric Cointegration and Dynamic Multipliers in a Nonlinear ARDL Framework. In Festschrift in Honor of Peter Schmidt, 281, 2014.

32. GREGORY A.W., HANSEN B.E. Residual-based tests for cointegration in models with regime shifts. Journal of Econometrics, 70 (1), 99, 1996.

33. GREGORY A.W., HANSEN B.E. Tests for cointegration in models with regime and trend shifts. Oxford Bulletin of Economics and Statistics, 58 (2), 555, 1996.

34. TODA H.Y., YAMAMOTO T. Statistical inference in vector autoregressions with possibly integrated processes. Journal of Econometrics, 66 (1-2), 225, 1995.

35. JAFORULLAH M., KING A. The econometric consequences of an energy consumption variable in a model of $\mathrm{CO}_{2}$ emissions. Energy Economics, 63, 84,. 2017. 